\title{
Multivariables Determining Earnings per Share within the U.S. Medical Laboratories \& Research Industry
}

\author{
Rishma Vedd \\ California State University, Northridge \\ 18111 Nordhoff, Northridge, CA 91330-8372, USA \\ Paul Lazarony \\ California State University, Northridge \\ 18111 Nordhoff, Northridge, CA 91330-8372, USA \\ Nataliya Yassinski \\ California State University, Northridge \\ 18111 Nordhoff, Northridge, CA 91330-8372, USA
}

\begin{abstract}
The objective of this study is to examine the key variables determining earnings per share for the Research Industry. In this study financial statements for ten years (from 2003 to 2012) of the publicly listed leading U.S. companies in the Medical Laboratories and Research Industry based on their size are gathered. In making proper decisions, we need to take into consideration such indicators as financial ratios, operating cash flows, and firm size. Since all of these factors indicate different aspects of the company's performance, each of those variables alone may not give the investor a complete and consistent estimate of the earning per share of a specific stock. Therefore, a multivariable regression analysis on the effect of firm size, financial ratios, and operating cash flows on earnings per share and the regression model used to predict the future earnings per share are utilized here. The objective is to analyze any significant relationships between those indicators and the earnings per share. The result indicates that the debt ratio, present value to book value ratio, and operating cash flow ratio have no significant relationship with earnings per share. The most significant predictors of earnings per share are the firm size, net profit margin ratio, return on equity ratio, current ratio, and total assets turnover ratio.
\end{abstract}

Keywords: Financial ratios, Earning per Share, U.S. market, Firm size, Cash Flow

\section{INTRODUCTION}

All investors have one goal in common, that goal course is to earn a capital gain on their investment. The significant tools for guiding investors to make investment decisions are financial indicators, such as financial ratios, operating cash flows, and the firm size. All of these financial indicators are considered when the rational investor is making such decisions. Among the questions that need to be taken into consideration is which financial indicators affect the investors' ultimate goal, of earnings? What are the relationships of those financial indicators with capital gains? Can any model that be developed that uses those financial indicators to predict future earnings? 
In attempting to answer these questions, these are steps that we have performed. The first is to decide on a target industry and five leading companies from within that industry. The next is to gather ten-years of financial information such as balance sheets, income statement, the statement of cash flow, and stock information from each selected company. A third step is to determine the financial ratios needed to perform this analysis, including earnings per share, firm size (natural logarithm of total asset), net profit margin ratio, return on equity ratio, current ratio, debt ratio, total asset turnover ratio, market value to book value ratio, and operating cash flow ratio. A natural next procedure is to develop a hypothesis. Finally the last step is to conduct a multivariable regression to determine any relationships among those financial ratios with earnings per share.

The medical laboratories \& research industry is the selected target industry because there is a satisfactory amount of required information available. The five publicly listed companies that are chosen for analysis in this study are Bio-Rad Laboratories, Inc., Laboratory Corp. of America Holdings, Quest Diagnostics, Inc., Thermo Fisher Scientific, and Bio-Reference Laboratories, Inc. Each of these five companies is leaders in the medical laboratories \& research industry in the U. S. For this reason the final developed model is a representative model for predicting the earnings per share for the entire industry.

This paper is composed of eight sections. The abstract section summarizes the purpose of the paper and briefly indicates the final conclusions and recommendations on the research. The introduction section gives more details on the purpose of the paper, how the analysis is designed and what the procedures are. The literature review is based on the similar research that has been done by others, including of the nature of the research and the conclusions. The data and methodology section breaks down the analysis procedures into details. It includes the definitions and conditions of the analysis. The results and discussion section represents all the findings I got from the regression analysis and the interpretation of those findings with statistical significance. The concluding comment section includes the conclusion and recommendations that have been derived from this analysis. The appendix section includes all the tables that are not shown in any other sections of the paper. Finally the reference section contains the citation of the references used to complete this research paper.

\section{LITERATURE REVIEW}

Financial statement analysis and the accuracy to predict stock returns is the topic that $\mathrm{Ou}$ and Penman [1] researched. In their research, they collected annual financial statement information from the COMPUSTAT annual report files, which contain most of firms that were traded on the NYSE and/or AMEX. The time period of collected data was from 1970 to 1984. In the paper, they analyzed all the financial statements they collected, studied the trading strategies of each publicly listed company, and finally used all the information and studies to develop a model of estimated earnings per share by running the multivariable regression. There were 68 financial indicators including all the common financial ratios and other information from financial statements had been included in the regression analysis. As a result, their research showed that equity values may not necessarily be reflected in the stock price and earnings predict. The associations between earnings predictors and future stock return capture a good deal of the contemporaneous associations between earnings and stock returns. Hull [2] extended the pure leverage change research and examined the effect of firm leverage ratio and industry leverage ratio on stock value, using the NYSE/AMEX and NASDAQ market indices. The research was based on two groups of samples, which contain 338 stock offerings that reduce debt. The results showed that a firm's leverage ratio changes have an effect on the market when the firm's debt-equity ratio (DE) changes relative to its industry DE norm. 
Vedd, R., Lazarony, P., \& Yassinski, N. (2014). Multivariables Determining Earnings per Share within the U.S. Medical Laboratories \& Research Industry. Archives of Business Research, 2(4), 150-160

The effect of financial ratios, firm size, and cash flow from operating activities in the interim report to the stock return is the research that was conducted by Martani, Khairurizka, and Khairurizka [3]. Their methodology involved collected financial statements from 39 publicly listed companies from Indonesian Capital Market Directory JSX Statistics. After running the regression analysis, they concluded in their research that financial ratios, firm size, and cash flow from operating activities altogether have an impact on stock returns.

The work of Faizatul Syuhada and Wan Mansor [4] examined the long-run and short-run relationship as well as predictive power between stock market, dividend yield and price earnings ratio by testing monthly data from 1989 - 2005 in Malaysian stock markets. The results indicated that there is long-run and short-run relationship among variables. In the short run, dividend yield has significant predictive power to stock return while stock returns has a significant negative relation to price earnings ratios. Moreover, the study showed that even though there is a predictive power from stock returns and price earnings ratios to dividend yield as well as from dividend yield and stock returns to price earnings ratios, they are not as significant as the predictive power from dividend yields and price earnings ratio to the stock return.

The studies of both Taani and Banykhaled [5] and Pouraghajan et al. [6] investigated the relationship among financial ratios, firm size, operating cash flows, and earnings per share. In Taani and Banykhaled's study, five categories of financial ratios were examined based on a sample of 40 companies listed in the Amman Stock Market. The research results showed that return on equity (ROE), Market ratio (PBV), cash flow from operation activities, and leverage ratio (DER) altogether has significant effect on earnings per share. Pouraghajan et al. (2013) used a sample of 140 companies in the Tehran Stock Market. The research results of Pouraghajan et al. (2013) were consistent with those of Taani and Banykhaled (2011). However, Pouraghajan et al. observed no significant relationship between operating cash flows and earnings per share.

In his research Dr. Shubita [7] researched the forecasting ability of earnings per share (EPS) and economic value added (EVA) for industrial Jordanian Companies. The study included 86 Jordanian shareholding companies listed in Amman Stock Exchange from years 2004 to 2009. Among these 86 companies, 38 were listed in the first market, and the rest were listed in the second market. The purposes of his research were to identify if the current earnings and financial ratio can be used to predict the future earnings, and if there were any relationships between EVA and EPS. After running the correlation and multiple regression analyses, his research concluded that, current earnings and financial ratio can be used to predict future earnings, the components of the current earnings can also be used to predict future earnings, but the economic value added may have no significant relationship with future earnings per share.

In the accounting and finance field, there is a continual discussion on the question of whether accrual accounting or cash accounting is a truer reflection of a business's operations and sustainability There is a common acknowledgment amongst accountants and finance professionals that the forecasted future cash flows of a firm have a direct effect on the price of a firm's stock. In their study, Freeman \& Gagne [8], examine the correlation between alternative measurements of cash flow and stock prices. They show that that there is a lower correlation between actual cash flow measurements and stock prices. However, there is a discrepancy when it comes to the matter of whether to use both unadjusted cash flows and accrual earnings when valuing a firm's stock. The researchers discuss that there is no 
uniformity in determining the best methods of stock evaluation. FASB believes that accrual earnings are more important whereas the finance theory is more concerned with the present value of future cash flows. J there should not be a competition between the use of unadjusted cash flows and accrued earnings because both are of significant importance y using data from COMPACT Disclosure and the Wall Street Journal, Freeman and Gagne were able to establish a hypothesis that both accrual earnings and traditional cash flows have a similar effect or correlation on stock prices, with traditional cash flows only being slightly more relevant.

The book-market value of equity ratio was once an often used financial ratio used to estimate stock returns. In their 1996 study Barbee, Mukherji, Raines [9] cite the work of Kothari, Shanken, and Sloan that proposed that this financial ration might not have as strong of a connection to stock returns as once was believed. While the book-market value of equity ratio is used as a gauge for the company's risk, it also has built in limitations that prevent it from being a completely accurate method of estimation. These limitations are a result of how the book value of a company is calculated.; The wide range of the figures that are used to calculate the book value are founded on such estimations as depreciation, estimated useful life, and inventory-accounting methods. Because of these limitations it may be beneficial to use other financial ratios to estimate the return of a stock. An excellent alternate ratio, the authors suggest is to use a stock return estimation that is based on sales-price ratio (price to sales ratio). These annual sales can prove to be more reliable than the estimated value of a business. This value has the benefit of using a sales-price are that it can never be a negative number; it is less affected by temporary events, and provides a truer idea of the stock's popularity amongst the investment community when the sales-price ratios impact on stock returns was compared to that of book-market value ratio, the market value ratio, and debt-equity ratio, the sales-price ratio was found to have a stronger correlation by almost 60\% (Barbee, et, al., 1996).

In a study by Patel [10], the author asked the question of: Do smaller firms have a higher risk and thus higher rate of return in comparison to larger more developed firms? To address this she performed specific calculations and analytical procedures to six selected stock market indices and analyzed the results for the period of July 1996 to December 2010 to obtain her results. The most pertinent question for this research was: The results proved that yes, smaller firms have both a higher risk and higher returns; nevertheless, when significance tests were performed on the results it was noted that the difference in the returns was not significantly different. It was noted that these findings are only relevant for the current period and are not indicative of past or future periods (Patel, 2012).

\section{DATA AND METHODOLOGY}

As is previously mentioned, five U.S. publicly listed companies from the medical laboratories \& research industry have been selected in order to conduct this research. The historical and present financial statements data from 2003 to 2012 has been collected from each company.

To determine the potential effect of firm size (defined as the "natural logarithm of the total assets of a company" which is a proxy for size of a firm), financial ratios, and operating cash flow on earnings per share, a regression analysis is conducted to test the following hypotheses:

○ H1: There is significant relationship between firm size and earnings per share.

O H2: There is significant relationship between net profit margin ratio and earnings per share.

○ H3: There is significant relationship between return on equity ratio and earnings per share.

- H4: There is significant relationship between current ratio and earnings per share.

$\circ$ H5: There is significant relationship between debt ratio and earnings per share. 
- H6: There is significant relationship between total asset turnover ratio and earnings per share.

- H7: There is significant relationship between market value to book value ratio and earnings per share.

- H8: There is significant relationship between operating cash flow ratio and earnings per share.

The IBM SSPS has been used to run the multivariable regression analysis to find the relationship between the earnings per share and the independent variables. An equation which can be confidently used to predict future earnings per share is a desired outcome at the end. Any independent variables that do not have significant relationship with the earnings per share, should be listed but provided with explanations. The T student test is used to test the significance of all estimated coefficients of all independent variables of this multivariable regression analysis; in addition, the Fisher $\mathrm{F}$ test is used to indicate the significance of the regression analysis and the final equation. Since the $95 \%$ of the significance level has been adopted, any independent variables whose significant of $\mathrm{F}$ statistic is lower than $5 \%$ will be considered having a significant relationship with earnings per share. On the other hand, for those independent variables whose significance of the $\mathrm{F}$ statistic is greater than $5 \%$ will be considered having an insignificant relationship with earnings per share. The R2 is used to indicate the predictive power for the regression model, the larger the R2, the more the independent variables can be explained by the regression model. Table 1 below discusses the calculation methodology of the variables using the regression model.

The equation (1) to test those hypotheses is developed as the following:

$$
\begin{aligned}
& E P S_{n}=\beta_{0}+\beta_{1} * T A_{n}+\beta_{2} * N P M_{n}+\beta_{3} * R O E_{n}+\beta_{4} * C R_{n}+\beta_{5} * D E R_{n}+\beta_{6} * T A T O_{n}+ \\
& \beta_{7} * P B V_{n}+\beta_{8} * C F O / \text { Sales }_{n}
\end{aligned}
$$

Where:

- EPSn represents the earnings per share of any U.S. medical laboratories \& research industry company in year $n$;

- TAn (the nature logarithm of the total assets) represents the firm size of any U.S. medical laboratories \& research industry company in year n;

- NPMn represents the net profit margin ratio of any U.S. medical laboratories \& research industry company in year $n$;

- ROEn represents the return on equity ratio of any U.S. medical laboratories \& research industry company in year n;

- CRn represents the current ratio of any U.S. medical laboratories \& research industry company in year $n$;

- DERn represents the debt ratio of any U.S. medical laboratories \& research industry company in year $n$;

- TATOn represents the total assets turnover ratio of any U.S. medical laboratories \& research industry company in year $\mathrm{n}$;

- PBVn represents the market value to book value ratio of any U.S. medical laboratories \& research industry company in year n;

- CFO/Salesn represents the operating cash flow ratio of any U.S. medical laboratories \& research industry company in year $\mathrm{n}$; and

- $\beta 0$ is the constant coefficient and the $\beta 1$ to $\beta 8$ are the coefficients of all independent variables in the regression equation. 
Table 1. How to calculate the variables used in the regression model

\begin{tabular}{|l|l|}
\hline Variables & Calculation Methodology \\
\hline EPS & $\begin{array}{l}\text { It is calculated by dividing the net profit of the chosen companies on the number } \\
\text { of their outstanding ordinary shares }\end{array}$ \\
\hline TA & $\begin{array}{l}\text { The natural logarithm of the total assets of those companies are used for the } \\
\text { regression analysis }\end{array}$ \\
\hline NPM & It is calculated by dividing the net profit on net sales \\
\hline ROE & Divide the net profit after tax by the equity's book value \\
\hline CR & Divide the current assets by the current liability of chosen companies. \\
\hline DER & It is calculated by dividing the total debt on total equity \\
\hline TATO & It is calculated by dividing the net sales on total assets \\
\hline PBV & Divide the market value of company's equity by its book value \\
\hline CFO/Sales & It is calculated by dividing cash flow from operating activities on net sales \\
\hline
\end{tabular}

\section{RESULTS AND DISCUSSION}

All of the collected and processed financial data from 2003 and 2012 for five U.S. publicly listed companies from the medical laboratories \& research industry provided the results that are based on the design model. Those results from Tables 2, 3 and 4 lead to the conclusions about the effects of financial ratios, firm size, and operating cash flows on earnings per share.

Table 2. Model Summary

\begin{tabular}{|c|c|c|c|c|}
\hline Model & $\mathrm{R}$ & R Square & Adjusted R Square & Std. Error of the Estimate \\
\hline 1 & $.917^{\mathrm{a}}$ & .841 & .810 & .99025 \\
\hline \multicolumn{7}{|l}{ a. Predictors: (Constant), CFO_Sale, PBV, DER, TATO, CR, NPM, TA, ROE } \\
\hline
\end{tabular}

Table 2 above shows the Model Summary table, since the $\mathrm{R}^{2}$ is equal to 0.841 , which indicates that the $84.1 \%$ of the variation in earnings per share can be explained by the variability in all the independent variables that the regression model we developed in predicting the earnings per share.

Table 3. ANOVA ${ }^{\mathrm{a}}$

\begin{tabular}{||l|r|r|r|r|r|}
\hline Model & Sum of Squares & df & Mean Square & F & Sig. \\
\hline Regression & 212.989 & 8 & 26.624 & 27.150 & $.000^{\mathrm{b}}$ \\
\hline Residual & 40.205 & 41 & .981 & & \\
\hline Total & 253.193 & 49 & & & \\
\hline \\
a. Dependent Variable: EPS \\
\hline
\end{tabular}

Table 3 above shows that the p-value associated with Sig. F is 0.000 ; this indicates that the regression model as a whole is a reliable predictor of future earnings per share. This reliability however, it may not accurate when coefficients table are considered. As mentioned earlier, a confidence level of $95 \%$ has been adopted to run this multivariable regression. This $95 \%$ chance that the relationship among the variables are not due to chance means that only those independent variables whose p-value are less than $0.05(5 \%)$ are considered as having a significant relationship with the earnings per share. The remaining independent variables with a p-value greater than 0.05 , therefore have no significant relationship with earnings per share in the regression model. A smaller p-value indicates that the independent variable has a direct linear relationship with the earnings per share. 
Table 4: Coefficients ${ }^{\mathrm{a}}$

\begin{tabular}{|c|c|c|c|c|c|c|c|}
\hline \multirow[b]{2}{*}{ Model } & \multicolumn{2}{|c|}{$\begin{array}{l}\text { Unstandardized } \\
\text { Coefficients }\end{array}$} & \multirow{2}{*}{$\begin{array}{c}\begin{array}{c}\text { Standardi } \\
\text { zed }\end{array} \\
\text { Coefficients } \\
\text { Beta }\end{array}$} & \multirow[b]{2}{*}{$\mathrm{t}$} & \multirow[b]{2}{*}{ Sig. } & \multicolumn{2}{|c|}{$\begin{array}{l}95.0 \% \text { Confidence } \\
\text { Interval for B }\end{array}$} \\
\hline & $\mathrm{B}$ & $\begin{array}{l}\text { Std. } \\
\text { Error }\end{array}$ & & & & $\begin{array}{l}\text { Lower } \\
\text { Bound }\end{array}$ & $\begin{array}{l}\text { Upper } \\
\text { Bound }\end{array}$ \\
\hline $\begin{array}{l}\text { (Const } \\
\text { ant) }\end{array}$ & -10.014 & 3.797 & & $\begin{array}{r}- \\
2.637\end{array}$ & .012 & -17.682 & -2.345 \\
\hline TA & 1.012 & .350 & .741 & $\begin{array}{r}2.88 \\
7\end{array}$ & .006 & .304 & 1.720 \\
\hline NPM & 31.728 & 7.623 & .555 & $\begin{array}{r}4.16 \\
2\end{array}$ & .000 & 16.334 & 47.123 \\
\hline ROE & .000 & .000 & .806 & $\begin{array}{r}2.35 \\
4\end{array}$ & .023 & .000 & .000 \\
\hline CR & -.809 & .386 & -.309 & $\begin{array}{r}- \\
2.096\end{array}$ & .042 & -1.588 & -.029 \\
\hline DER & -2.209 & 2.508 & -.108 & -.881 & .384 & -7.274 & 2.856 \\
\hline TATO & 3.208 & .911 & .683 & $\begin{array}{r}3.52 \\
0\end{array}$ & .001 & 1.367 & 5.048 \\
\hline PBV & $\begin{array}{r}1.416 \mathrm{E}- \\
6\end{array}$ & .000 & .199 & .581 & .565 & .000 & .000 \\
\hline $\begin{array}{l}\mathrm{CFO}_{-} \\
\text {Sale }\end{array}$ & -1.537 & 8.686 & -.032 & -.177 & .860 & -19.078 & 16.004 \\
\hline
\end{tabular}

a. Dependent Variable: EPS

Table 4 above displays the coefficients of each independent variable related with the earnings per share. According to those coefficients, the regression model can be provided as:

$\mathrm{EPS}_{\mathrm{n}}=-10.014+1.012 \mathrm{TA}_{\mathrm{n}}+31.728 \mathrm{NPM}_{\mathrm{n}}+0.000107 \mathrm{ROE}_{\mathrm{n}}-0.809 \mathrm{CR}_{\mathrm{n}}-2.209 \mathrm{DER}_{\mathrm{n}}+3.208$ $\mathrm{TATO}_{\mathrm{n}}+1.416 \mathrm{E}-6 \mathrm{PBV}_{\mathrm{n}}-1.537 \mathrm{CFO} /$ Sales $_{\mathrm{n}}$

There are several interpretations that can be gleaned from this regression equation.The first is that each additional unit increase in the firm size (the natural logarithm of the total assets), yields average earnings per share increases of $\$ 1.012$, controlling for firm size. Furthermore each additional unit increase in the net profit margin ratio, the average earnings per share increases by $\$ 31.728$, controlling for net profit margin ratio. A unit increase in return on equity ratio, shows average earnings per share increase of $\$ 0.000107$, controlling by return on equity. An additional unit increase in current ratio, decreases average earnings per share by $\$ 0.809$, controlling by current ratio. A unit increase in debt ratio, results in average earnings per share that decrease by $\$ 2.209$, controlling by debt ratio. Average earnings per share would increase by $\$ 3.208$ for each additional unit increase in total assets turnover ratio, controlling by total assets turnover ratio. An additional unit increase in present value to book value ratio, yields an average earnings per share increase by $\$ 1.416 \mathrm{E}-6$, controlling by present value to book value ratio. Average earnings per share decrease by $\$ 1.537$, for each additional unit increase in operating cash flow ratio, controlling by operating cash flow ratio. The constant coefficient of - 
10.014 is used to adjust the sum of all independent variables after their individual coefficients are multiplied to come up with the final earnings per share.

The results of the regression analysis indicate that the company size, net profit margin ratio, return on equity, current ratio, and the total assets turnover ratio have, respectively p-values of $0.006,0.000157,0.023,0.042$, and 0.001 . This indicates that we can rely on these independent variables to predict the earnings per share of any U.S. companies that operate in the medical laboratories \& research industry. In addition to those significantly related independent variables, there are also some independent variables in the regression model that are not accurate predictors of future earnings per share. The independent variables of debt ratio, present value to book value ratio, and operating cash flow ratio, on the other hand, do not have a significant relationship with earnings per share and thus they cannot be used to predict future earnings per share for medical laboratories \& research industry companies. These variables have respectively, p-values that are $0.384,0.565$, and 0.860 and all of these are greater than the required significance level 0.05 .

\section{CONCLUDING COMMENTS}

Earlier in this study eight hypotheses were made. After testing each of these, the conclusion here is that the only significant relationship with earnings per share, are the independent variables of company size, net profit margin ratio, return on equity, current ratio, and the total assets turnover ratio. Only these can be used to predict the future earnings per share. The debt ratio, present value to book value ratio, and operating cash flow ratio all failed the significance test; therefore they have no significant relationship with earnings per share and cannot be used in the regression model. The variables of firm size, financial ratios, and operating cash flow may all be important information for the investor to make decisions on their investment. These factors, however, provide inadequate information for investors. For those investors who have a limited financial and accounting backgrounds, it is hard to interpret this information and make correct decisions. A simple regression equation of earnings per share may be desired by those investors in order to understand the business in which they are going to invest, and to get a plausible projection of the future return. The accuracy of this model indicates the success of the regression model on earnings per share.

Some independent variables do have a significant relationship with the earnings per share, but others have no significant relationship with earnings per share, so if they are still included in the regression model for predicting the future earnings per share, the estimated result may be significantly flawed, which makes the estimation useless. Therefore to ensure the estimated prediction to be as accurate as possible, it is highly recommended that those insignificantly related independent variables be removed from the regression model. This regression model will thus provide a more accurate estimation of the earnings per share. The following new model explains in Tables 5, 6 and 7 is the most suitable variables for determining future earnings per share.

Table 5: Model Summary

\begin{tabular}{|c|r|r|r|r|}
\hline Model & R & R Square & Adjusted R Square & \multicolumn{1}{c|}{$\begin{array}{c}\text { Std. Error of the } \\
\text { Estimate }\end{array}$} \\
\hline 1 & $.913^{\mathrm{a}}$ & .834 & .816 & .97594 \\
\hline
\end{tabular}

a. Predictors: (Constant), TATO, CR, NPM, ROE, TA

The most accurate version of the new regression model in Table 5, only contains the independent variables of the company size, net profit margin ratio, return on equity, current ratio, and the total assets turnover ratio. Comparing with the original model, in the new model 
Vedd, R., Lazarony, P., \& Yassinski, N. (2014). Multivariables Determining Earnings per Share within the U.S. Medical Laboratories \& Research Industry. Archives of Business Research, 2(4), 150-160

the $\mathrm{R}^{2}$ is 0.834 , which is a decrease of $0.7 \%$, and the standard error of the estimate is decreased by $1.4 \%$ from 0.990 to 0.976 . The new regression model may only explain $83.4 \%$ of the earnings per share; the standard error decreased more, so the new regression model is considerably more accurate.

Since the new regression model only includes the independent variables that have a significant relationship with earnings per share, the p-values of each of these are all less than 0.05 . The new regression model therefore can reliably be used to predict future earnings per share for any U.S. companies operating in medical laboratories \& research industry.

Table 6: New ANOVA ${ }^{\mathrm{a}}$

\begin{tabular}{|c|r|r|r|r|r|}
\hline Model & Sum of Squares & df & Mean Square & F & Sig. \\
\hline Regression & 211.285 & 5 & 42.257 & 44.366 & $.000^{\mathrm{b}}$ \\
Residual & 41.908 & 44 & .952 & & \\
Total & 253.193 & 49 & & & \\
\hline
\end{tabular}

a. Dependent Variable: EPS

b. Predictors: (Constant), TATO, CR, NPM, ROE, TA

Table 7: Coefficients ${ }^{\mathrm{a}}$

\begin{tabular}{|c|c|c|c|c|c|c|c|}
\hline \multirow[b]{2}{*}{ Model } & \multicolumn{2}{|c|}{$\begin{array}{l}\text { Unstandardized } \\
\text { Coefficients }\end{array}$} & \multirow{2}{*}{$\begin{array}{c}\begin{array}{c}\text { Standardi } \\
\text { zed }\end{array} \\
\text { Coefficients } \\
\text { Beta }\end{array}$} & \multirow[b]{2}{*}{$\mathrm{t}$} & \multirow[b]{2}{*}{ Sig. } & \multicolumn{2}{|c|}{$\begin{array}{l}95.0 \% \text { Confidence } \\
\text { Interval for B }\end{array}$} \\
\hline & B & $\begin{array}{l}\text { Std. } \\
\text { Error }\end{array}$ & & & & $\begin{array}{l}\text { Lower } \\
\text { Bound }\end{array}$ & $\begin{array}{l}\text { Upper } \\
\text { Bound }\end{array}$ \\
\hline $\begin{array}{l}\text { (Const } \\
\text { ant) }\end{array}$ & -11.322 & 2.709 & & $\begin{array}{r}- \\
4.179\end{array}$ & .000 & -16.781 & -5.862 \\
\hline TA & 1.101 & .250 & .807 & $\begin{array}{r}4.40 \\
0\end{array}$ & .000 & .597 & 1.605 \\
\hline NPM & 29.742 & 4.831 & .520 & $\begin{array}{r}6.15 \\
7\end{array}$ & .000 & 20.006 & 39.477 \\
\hline ROE & .000 & .000 & .973 & $\begin{array}{r}9.18 \\
4\end{array}$ & .000 & .000 & .000 \\
\hline CR & -.601 & .283 & -.230 & $\begin{array}{r}- \\
2.128\end{array}$ & .039 & -1.171 & -.032 \\
\hline TATO & 3.271 & .853 & .696 & $\begin{array}{r}3.83 \\
5\end{array}$ & .000 & 1.552 & 4.990 \\
\hline
\end{tabular}

a. Dependent Variable: EPS

The new regression model has the following formula according to the results in Tables 6 and 7 is:

$\mathrm{EPS}_{\mathrm{n}}=-11.322+1.101 \mathrm{TA}_{\mathrm{n}}+29.742 \mathrm{NPM}_{\mathrm{n}}+0.000129 \mathrm{ROE}_{\mathrm{n}}-0.601 \mathrm{CR}_{\mathrm{n}}+3.271 \mathrm{TATO}_{\mathrm{n}}$ 
This regression model can be interpreted that:

- For each additional unit increase in the firm size (the natural logarithm of the total assets), average earnings per share would increase by $\$ 1.101$, controlling for firm size.

- For each additional unit increase in the net profit margin ratio, average earnings per share would increase by $\$ 29.742$, controlling for net profit margin ratio.

- For each additional unit increase in return on equity ratio, average earnings per share would increase by $\$ 0.000129$, controlling by return on equity.

- For each additional unit increase in current ratio, average earnings per share would decrease by $\$ 0.601$, controlling by current ratio.

- For each additional unit increase in total assets turnover ratio, average earnings per share would increase by $\$ 3.271$, controlling by total assets turnover ratio.

- -11.322 is the constant coefficient that will adjust the sum of all independent variables after multiple their individual coefficient to come up with the final earnings per share.

This new model will give investors a better view of the stock's potential earnings per share and assist them to make the right choices. The new regression model excluded any insignificant variables, so the differences between the estimation and actual earnings per share will be less and because of this, the standard error on the estimated is reduced.

\section{References}

[1]. Ou, J. A., \& Penman, S. H. $(1989,11)$. Financial statement analysis and the prediction of stock returns. Retrieved from http://ideas.repec.org/a/eee/jaecon/v11y1989i4p295-329.html

[2]. Hull, R. M. (1999). Leverage ratios, industry norms, and stock price reaction: An empirical investigation of stock-for-debt transactions. Financial Management, 28(2), 32-45. Retrieved from http://search.proquest.com/docview/208181510?accountid=7285 8

[3]. Martani, D., Khairurizka , M., \& Khairurizka , R. $(2009,6)$.The effect of financial ratios, firm size, and cash flow from operating activities in the interim report to the stock return. Retrieved from http://staff.ui.ac.id/system/files/users/martani/publication/5theeffectoffinancialratiosfirmsizeandcashflowfromoperatingactivitiesintheinterimreportto.pdf

[4]. Faizatul Syuhada, A. F., \& Wan Mansor, W. M. (2011). Multivariate causal estimates of dividend yields, price earnings ratio and expected stock returns: Malaysian evidence. International Journal of Financial Management, 1(1) Retrieved from http://search.proquest.com/docview/1478007258?accountid=7285

[5]. Taani, K., \& Banykhaled, M. H. H. (2011). The effect of financial ratios, firm size and cash flows from operating activities on earnings per share: (an applied study: on Jordanian industrial sector). International Journal of Social Sciences and Humanity Studies, 3(1), 1309-8063.

[6]. Pouraghajan, A., Mansourinia, E., Bagheri, S. M. B., Emamgholipour, M., \& Emamgholipour, B. (2013). Investigation the effect of financial ratios, operating cash flows and firm size on earnings per share: evidence from the tehran stock exchange. International Research Journal of Applied and Basic Sciences,4(5), 1026-1033.

[7]. Shubita, M. (2013, 11 18). EPS and EVA forecasting ability for industrial Jordanian companies. Retrieved from http://www.iiste.org/Journals/index.php/EJBM/article/view/6646

[8]. Freeman, G. R., \& Gagne, M. (1992). An investigation of the usefulness of cash flows: The effect of firm size. Journal of Applied Business Research, 8(4), 141. Retrieved from http://search.proquest.com/docview/227579953?accountid=7285

[9]. Barbee,William C.,Jr, Mukherji, S., \& Raines, G. A. (1996). Do sales-price and debt-equity explain stock returns better than book-market and firm size? Financial Analysts Journal, 52(2), 56. Retrieved from http://search.proquest.com/docview/219172570?accountid=7285

[10]. Patel, J. B. (2012). A further analysis of small firm stock returns. Managerial Finance, 38(7), 653-659. doi:http://dx.doi.org/10.1108/03074351211233113 
Vedd, R., Lazarony, P., \& Yassinski, N. (2014). Multivariables Determining Earnings per Share within the U.S. Medical Laboratories \& Research Industry. Archives of Business Research, 2(4), 150-160

\section{ACKNOWLEDGEMENTS}

We would like to thank CSUN Masters' of Science in Accountancy students Nichole Cain, Daisy Weng, and Wenbo Zhou for their contributions to this project. 